\title{
A Critique on the Consequences of Priority of the Individual over the Community in the Contemporary African Context
}

\author{
Gerishon Kuria Njuguna \\ Senior Lecturer \\ Egerton University \\ Faculty of Arts and Social Sciences \\ Department of Philosophy, History and Religious Studies \\ P. O. Box 536-20115, Egerton \\ Kenya.
}

\begin{abstract}
The African person has changed his way of looking at himself and the universe due to modernity. At the heart of life in the traditional African community was the collective and communal formation of the person. Emerging issues in the contemporary society have caused disintegration of the moral fabric of society giving rise to an individualistic society. This paper provides a detailed analysis of consequences of priority of the individual over the community in the contemporary African context. It is established that the community's involvement in the formation of the individual is ignored. Modern education caters for the development of individual despising responsible participation in community's activities and peaceful coexistence. The close link between elders and youth has been severed. This paper concludes that the community is important to the individual since from it a person draws personhood. The need to salvage and enrich some traditional African values is also underscored.
\end{abstract}

Keywords: Consequences, Individual, personhood, community, society

\subsection{Introduction}

Questions are often raised as to why the present generation of Africans is different from the traditional one. In this paper we explore the traditional African understanding of the community and the individual. This is followed by reflection on the importance of community for an individual and how the individual person participates in the life of the community. This paper demonstrates the shortcomings of emphasizing the individual over the community. In order to avoid further disintegration of the moral and social fabric of African societies, the African family synergy should be salvaged. This, the researcher contends, is the foundation for recovering and promoting African values and identity. Individualism in the positive sense would work at cross-purposes with Plato's idea of the ideal society. In such a society an individual was a means to the good of society. The individual exists for the sake of collectivity but not collectivity for the sake of the individual. Recognition of individualism in the positive sense would imply acknowledgement of uniqueness of persons as ends in themselves and with rights as human beings. Plato's conception of justice in his Republic is also indicative of a totalitarian attitude that each person should only play the role assigned to him in society without choice so that harmonious existence can be created and maintained.

\subsection{Notion of the Community}

In a definitional context, a community is a social political arrangement usually made up of persons, groups of persons who are linked together by interpersonal bonds, which are not necessarily biological (Fayemi, Ademola, Kazeem 2009). We understand the community to be predicated on the social being and belongingness of people with communal values, which serve as the foundational basis of communalism, which define and guide social relations in the form of attitudes and behavior that should exist between individuals living together in a community who not only share social life but also a sense of common good. Such values include sharing resources, burden and social responsibility, mutual aid, caring for others, inter-dependence, solidarity, reciprocal obligation, social harmony and mutual trust. (Oyeshile, Olatunji 2006).

According to Nkemnkia (1999), African identity and culture are founded on the intimate and vital unity with the family, the tribe and God. The 'I' is not the point of departure but the "You", the "We", the collectivity of the community and tribe. The individual cannot organize or fulfill himself outside the community, clan or tribe; he would be like a fish out of water. In this case the meaning of the 'I' emerges in the concept of others. 
According to the Gikuyu way of thinking, nobody is an island. One's uniqueness is a secondary fact; first and foremost he is several people's relative and several people's contemporary. "Individualism and self- seeking were ruled out ... The personal pronoun 'I' was used very rarely in public assemblies. The spirit of collectivism was ingrained in the mind of the people" (Kenyatta1965).

It is quick to assume that this philosophy with its emphasis on communal values, collective good and shared ends, communitarianism invariably conceives the person as wholly constituted by the social relationships, that it tends to whittle down the moral autonomy of the person; "that it makes the being and life of the individual person totally dependent on the activities, values, projects, practices and ends of the community and consequently, that it diminishes his/her freedom and capability to choose or question or re-evaluate the shared values of the community (Gyeke 2001).

Although the basic thrust of communitarianism is that instead of such values as individual interest, autonomy, universality, natural rights and neutrality, communitarian philosophy is framed in terms of the common good, social practices and traditions, character, solidarity and social responsibility. It is this collectivity which leads other thinkers to the radical conclusion that the individual finds him or herself drowned in the community. In this case there is the superiority of the "We" over the "I". This is also the understanding of John Mbiti (1990) in his book, African Religions and philosophy. Mbiti holds that the community controls social relationships. He holds that the community determines the behaviour of an individual towards another. Accordingly, a person is what he is in virtue of what he is predestined to be, his character, and the communal influence on him. It is a combination of these elements that constitute human personality.

This is why the community is the author and guardian of moral norms. Therefore the individual does not and cannot create moral norms ex nihilo. The individual has to be identified with something already existing, i.e. the community. An individual is not born tabula rasa, there are norms, customs, rules, beliefs and practices he finds already in the community. This is best echoed by Bujo (1988) who holds that one cannot avoid or pass the experiences of one's ancestors, who established the ethical norms based on wisdom arising out of the community.

The African values, rituals, taboos and practices that have already been tried and tested, preserve the community's life from disintegration; moreover, they ensure the growth of the total life force. That is why the community is not:

a mere association of individual persons whose interest and ends are contingently congruent but a group of persons linked by interpersonal bonds, biological and /or non-biological who consider themselves as members of the group and who have common interests, goals and values (Gyeke 2001).

Community is more than a multitude of individual men and women gathered in one place. It is a kind of organism where an individual forms only part. Thus an individual cannot stand alone. An individual has significance and value only insofar as a member of such a community.

\subsection{The Reciprocal Existence of the Individual and the Community}

If the community exists, then the individual exists. The individual exists therefore the community exists. This is the vital union and relationship between the individual and the community, between human beings, between nature and God and extends to the departed members of the community.

The whole of African society, living and living dead, is a living network of relations almost like that between the various parts of an organism. When one part of the body is sick the whole body is affected. When one member of a family or clan is honoured or successful, the whole group rejoices and shares in the glory, not only psychologically but ontologically, each member of the group is really part of the honour (Ntumba 1985).

On the similar note, Rousseau (1994) thinks the general will is concerned only with common interest. "The common interest takes away individual desires, excesses and insufficiencies. What remains as a common element from different desires is the common will". The decision coming from the general will is always good. This is the way the community is understood, the individuals give themselves to the community for their own actualization.

A person whose existence and personality is dependent on the community is expected in turn to contribute his own quota to the continued existence of the community, which nurtures him and partakes in his destiny. This is the ultimate meaning of human existence. The crown of personal life is to bear fruit (beget offspring); the crown of communal life is to be useful to the one's community. The meaning of one's life is measured by one's commitment to social ideals and communal existence (Gbadegesin and Segun 1992).

In the Western philosophical tradition, according to Nkemnkia (1999), thought is articulated through assumed concepts paradigmatically as categorical and universal values. For the African, on the other hand, every concept and value is part of a whole, not yet specified. This explains why community is not merely collective. The community has always to be realized and is never full. It is dynamic. Hence community is open to the individual and the individual is also open to the community. 
One has to remember that the whole is made up of parts. Therefore it would be absurd and impossible to think of a "whole" without its parts. It would be equally difficult to imagine the parts without having an idea of the "whole" to which they belong" (Nkemnkia 1999).

Common interest and values define the notion of the community. Since members share goals and values, they are ready to pursue and defend them. According to Gyekye (1988) they have intellectual and ideological, as well as emotional, attachments to those goals and values. When we lay emphasis on the individual rather than the community, there is competition of man by man, which leads to the emergence of moral, political and social evils. This paper contends that the most reasonable option for an African is to learn something from his/her traditional roots, which can be a panacea to some of the many social problems experienced today.

For the Ghanaian philosopher Gyekye (1988), the individual, although originating from and intrinsically bound to his family and community, nevertheless possesses a clear concept of himself as distinct person of volition. It is from this combined sense of personhood and communal membership that the family and community expect individuals to take personally enhancing and socially responsible decisions and actions.

Although he accepts that the dominant entity of African social order is the community, Gyekye (1988) believes it would be more correct to describe that order as amphibious, for it manifests features of both communality and individuality. African social thought seeks to avoid the excesses of the two exaggerated systems, while allowing for meaningful, albeit uneasy, interaction between the individual and the society.

Senghor (1963) while agreeing with Gyekye (1988) regards traditional African society to be based both on the community and on the person and in which, because it was founded on dialogue and reciprocity, the group had priority over the individual without crushing him but allowing him to blossom as a person. Citing the Xhosa proverb Umuntu ngumuntu ngabantu (a person is a person through persons) Augustine and Shutte writes: "This proverb is the Xhosa expression of a notion that is common to all African languages and traditional cultures...It is concerned both with the peculiar interdependence of persons on other for the exercise, development and fulfillment of their powers that is recognized in African traditional thought, and also with the understanding of what it is to be a person that underlies this...In African thought it is seen as 'outside,' subsisting in relationship to what is other, the natural and social environment. In fact the sharp distinction between self and world, a self that controls and changes the world and is in some sense 'above' it, this distinction so characteristic of European philosophy disappears. Self and the world are united and intermingle in a web of reciprocal relations" (Augustine and Shutte 1993).

In contrast to Gyekye's (1988) mutually enhancing understanding and Shutte's idea that the community empowers and inculcates 'personess,' Nyasani (1997) observes that the African individual hardly knows how to act outside the context of his community's prescriptions and proscriptions. For Nyasani the existence of the individual in African society is a "quasi-dissolution into the reality of others for the sake of the individual's existence".

For Nyasani, (1997) everything boils down to the 'me' in the 'we' or rather to the survival of the self through the enhancement and consolidation of the 'we' as a generic whole... Thus in Africa, the individual will go to all lengths to ascertain the condition of the corporate 'we' and to play his part, if necessary, to restore the balance of wholesomeness.

\subsection{Ontological Primacy of the community}

This paper contends that community is an ontological reality. This understanding is based on the idea of vital force. Vital force is life as such not merely as manifested in a living being. This is in line with Tempels (1969) who observes that the purpose of Bantu existence is to acquire life, strength or vital force, to live strongly, that they are to make life stronger or to assure that force remains perpetually in one's posterity.

When the Bantu talk about vital force, God is its epitome. God is referred as the "strong one". The rationale is that God possesses force in Himself, being the creator. He is the source therefore of everything. All creatures participate in this common life of God, the vital force. Tempels (1969) uses vital force not in the exclusively bodily sense but in the sense of the integrity of being.

For the Bantu, force is a necessary element in being, and the concept of force is inseparable from the definition of being. There is no idea among the Bantu of being divorced from the idea of force. Without the element of force, being cannot be conceived (Tempels 1969). Therefore vital force cannot be separated from the definition of being. It's this vital force then which is the substratum that holds being or beings together. That is why the supreme happiness, the only kind of blessing, is to the Bantu, to posses the greatest vital force, the worst misfortune and in every truth, the only misfortune is, he thinks, the diminution of this power (Tempels 19969). Among the Bantu, the concept of 'vital force' is common, for it is that which links different beings. That is, it has the power that allows beings to participate negatively or positively into each other's life. This is possible because according to Nkemnkia (1999), it is the life common to all men and in virtue of the unified vision of reality. 
Consequently the civilization and the culture of a people are characterized by the category of "relation", which makes African civilization, a civilization of relation "between man and nature, between man and the supernatural that is the vital force which is God, who communicates himself to man and to everything. Being and life cannot be separated from each other. This life is manifested in being. It is the force in being and without being this force cannot be manifested. Tempels (1969) concluded that being is force and force is being. Where being is, there is force and where force is, being is there also. Consequently life is first, for it is manifested in being. That is why life is that which is common to all beings.

Life which is common in all beings is that reality which exists in everything in the universe. Life is that which is ontologically common to all beings. It is that which the source of their being is. Kanyike (2004) expresses it in another way when he says that Man has something of God and of his ancestors i.e. he is ontologically linked to the spiritual world and so he has access to it. The spiritual and the physical worlds interact with each other and promote each other. John Mbiti (1990) captures this ontology in his famous adage "Africans are notoriously religious... Religion permeates into all departments of life so fully that it is not easy or possible always to isolate it". From Mbiti's assertion Bantu ontology can only be understood from a religious point of view. Here vital force has to flow from God who is the source and creator of all beings. This reminds us of the idea of community which consists in sharing things in common as is the case of vital force.

Community has an Ontological connotation which Mbiti (1990) expresses in "To be is to belong to the whole community and to do so involves participating in the beliefs, ceremonies, rituals and festivities of the community". Hence the individual is aware of his existence only if he/she is linked to the community. One cannot, normally, live detached from the community; "to do so is to be severed from his roots, his foundation, his context of security, his kinship and the entire group of those who make him aware of his own existence (Mbiti 1990). Consequently Mbiti (1990) contends that people simply assimilate whatever religious ideas and practices are held or observed by their families or communities. In this he emphasizes the role that the community plays for the individual, by shaping his or her values, thought processes and opinions.

Therefore a person belongs to a particular society through which s/he assimilates the religious traits of that society to which he/she belongs. Thus the basis of unity or community is not the common nature of Aristotelianism. It is rather through participation in the community's beliefs.

\subsection{Community as composed of individuals}

The fundamentally relational character of the person and the interdependence of human individuals, arising out of their natural sociality are, on the basis of the preceding discussion, obvious. It is these necessary relationships which complete the being of the individual person who, without entering into these relationships, would not be complete. Gyekye (2001) corroborates this point in the excerpt below.

In the social context, in terms of functioning or flourishing in a human community, the individual person is not selfsufficient, his/her capacities, talents and dispositions are not adequate for the realization of his potential and basic needs..., what accrues from the person's natural sociality - and hence natural rationality - provides the buttress indispensable to the actualization of his/her possibilities.

This means that an individual person is helpless without community. One is born and bred in community. S/he needs the community economically, socially, religiously, and so forth. The community is, in this case, paramount in an individual's existence. An individual needs the community as the community needs individuals. Therefore there is interdependence between the community and individuals. This is captured in Mbiti's famous assertion: "I am because we are, and since we are therefore I am" (Mbiti (1990). The individual cannot exist alone except communally. He owes his/her existence to other persons; the past generations, his contemporaries and the generations to come. Man is therefore a social animal who must always be in relationship with others for community to exist.

Contributing to the same idea, Nkemnkia (1999) observes that; Man is the most social being ever known on earth. This is because he is able to relate to others, with his own kind, with the surrounding world and with God, his creator. For this very reason, he is always a member of a society, without which he loses their value. Due to the multiplicity of the others, of the individual, the meaning of life is hidden within the dialectic of the collective or the community.

With such a conception, the meaning of individual life is found in and through the relationship with others. "In fact it is meaningless to ask oneself" who am I" without having complete knowledge of the other, from whom, in the final analysis, one expects the answer. When one says "I", one in reality means "you", that is, the other. By saying "We" one is essentially saying "man."(Nkemnkia 1999). In this case then each "I" is always mediated by "the other". In this dialectic each one of us contains exclusively the other, in such a way that, if one wants to do good to the other, one needs to consider the other as a "self." 
Therefore in Africa man is thought only in terms of relationship. It follows in African culture it is uncommon to speak of "man" in the form of treatise or a concept, because it is not possible to describe a people in its totality and truth. Man is never considered as a problem of speculative nature. Man is not subject to purely abstract discussions. He always has the other in mind; and every human act is directed towards the other. Everyone is aware of the other's value to which human acts are devoted. Thus all human acts are motivated by love and solidarity with the other.

This love is the first characteristic of co-existence among human begins, without love, without brotherly love, which is always reciprocal, otherwise there will be no points of contact, there's no community and it is not possible to discover the meaning of life. Therefore even when clothing oneself or combing one's hair, the individual's behaviour presupposes always a point of reference: the other (Nkemnkia 199)

Among the Bantu for example, Nkemnkia (1999) observes that, the expression "Muntu" finds its meaning in the idea and reality of the other (man's neighbour). So, one can find the meaning of his own life only when he has found the meaning of the life of the other that is the place occupied by our neighbour in our life. Since the individual is within community he/she is simply part of the whole. Hence the community is responsible for creating or producing individuals. The community in this sense is of primary and central importance. It is not just a cultural value. It is the causal nexus independent of the world, time and space, the centre and mediator related with lineage, life and the human person (Beller 2001).

Bujo (1988) contends that only common actions make the human person a human and keeps him from becoming an unfettered ego. This is why any human being who behaves without consideration of interpersonal relationships and solidarity with the community is considered inhuman. Witches are suspected, for example, because they are dangerous to the community and so the community has to protect itself from them. The individual affirms his/her humanity when she/he acknowledges the humanity of others. The individual can only become human in the community; the muntu becomes muntu only within the community.

\subsection{The individual in the community}

Every individual is born in a particular community and must participate in the life of the community. The community in turn recognizes the individual by giving him status and responsibilities. Mbiti (1990) looks at the individual in the African community and observes that, a person has to be born a member of it and he cannot change tribal membership. Accordingly the person cannot be converted from one tribe to another. He belongs to a particular community. That is his/her individuality, personal responsibilities and rights are acknowledged and dominated by community.

In some communities when an individual undergoes initiation rights, he/she acquires personality and the community officially acknowledges him/her as its member. The individual knew she does not live of himself/herself but for the community and when the interests of the community are at stake, personal interests are of little importance, they must be sacrificed to community interest (Kanyike 2004).

Understood in this manner, the community is the one that protects, educates and renders services to the individual. It imposes duties and sanctions on its members and one realizes oneself only by serving the community.

No one is allowed to keep this vitality for oneself; everyone has to share it with the other members of the family or clan. This means that every member has to behave in such a way that all that is done contributes towards the development of life (Bujo 1988).

A person is therefore open and available to others, affirming of others. He does not feel threatened that others can harm him. He has proper self-assurance that comes from knowing that he belongs to a greater whole and is diminished when others are humiliated or diminished, when others are tortured or oppressed. It follows that one cannot exist as a human being in isolation. This implies that men and women are interconnected. One can't, in other words, be human all by oneself. Unfortunately, more often than not, people think of themselves as mere individuals, separated from one another, whereas they are connected and what one does affects the whole world. When one does good, it spreads out; it is for the whole humanity.

\subsection{Realization of Personhood in the Community}

In recent years some African philosophers have been involved in serious debate about whether somebody becomes a person at birth and so independent of the community or it is acquired, conferred or defined by the community. Menkiti (1984) observes that in Africa babies and minors are addressed with the pronoun 'it'. It means that children are not grown enough to acquire personhood. In this regard, he argues that the relative absence of ritualized grief over the death of a child in African societies in contrast to the elaborate burial ceremony and ritualized grief in the event of the death of an older person supports his point about the conferment by the community of the personhood status." Here we have alluded that a person is born in the community. 
His life is part of the life force of the community. Nyasani (1991) supports this view by asserting that: my own individual life - force is not mine by right or by nature but a gratuitous conferment from the ex post facto reality of those who already enjoyed it and jealously safeguard it for the purpose of continuity, social cohesion, social harmony, social and physical integrity and for realizing the teleological good of human (African) existence-the Mitsein in perpetual communion and perpetual vitality.

Here the author asserts the ontological primacy of the community. The reality of the communal world takes precedence over the reality of the individual life. The person as such is communal and relating. He is wholly constituted by social relationships. In this sense it is the community which defines the person. The consequence of this understanding is that personhood is acquired. To be person is realized through a community which is endowed with the capacity to satisfy it. This means that not all people acquire personhood, some fail to as Mbiti (1990) clearly points out: Physical birth is not enough: the child must go through rites of incorporation so that it becomes fully integrated into the entire society. These rites continue throughout the physical life of the person, during which the individual passes from one stage of corporate existence to another.

\subsection{The Person as a Project}

We have so far seen that the community in African society took care of the individual in all dimensions and the individual contributed to the wellbeing of the community. Important to note here is the fact that the community molded the individual person in all dimensions and the individual made reference to the community for guidance. Society shares its wisdom, both theoretical and practical, to the initiates during the rites of passage. That is, the individual who is part of the whole becomes the guardian of what the society holds. He/she becomes custodian of community wisdom and norms. The initiate in this thinking discovers that he/she cannot be understood outside the community and his selfdetermination can only be understood in the context of the community. "The human being receives his subjectivity and identity through lineage, tradition and initiation (Beller 2001). Therefore to be human is to know how to live accordingly within society. Society does not hinder one's personality, but it harnesses and manifests it. It is especially during initiation that the community reveals the personalities of the initiates by realizing their new status in society. We can therefore conclude that it is only the person who is able to interact and participate in the life of the society that is able to discover himself/herself as a muntu.

\subsection{The Notion of the Person and the Common Good}

Personality by nature seeks communion. For the person requires membership in a society by virtue of both its dignity and its needs. Society in the proper sense is a society of persons. This is because of its very perfections as person and also because of its inner urge to communicate knowledge and affection which implies relationship with other persons. There is a correlation between this notion of the person as a social unit and the notion of the common good as the end of the social whole. They imply one another. The common good is common because it is received by persons, each one of whom is a mirror of the whole.

The end of the society therefore is neither the individual good nor the collection of the individual goods of each of the persons who constitute it. Such a conception would dissolve the society as such to the advantage of its parts and would amount to either a frankly anarchistic conception or the old disguised anarchistic conception of individualistic materialism, giving to the strong full freedom to oppress the weak (Maritain 1947).

Therefore purpose of society is the good of the community; of the social whole. This is the good of human persons. It is the good human life of the multitude of persons; it is their communion in good living. It is therefore common to both the whole and the parts into which it flows back and which it in turn must benefit from.

\subsection{Critical Reaction to the Radical Communitarian Conception of Personality}

Scholars like Edward Blyden, John Mbiti, Julius Nyerere, Kwame Nkrumah, Leopold Senghor, Bolaji Idowu and Ifeanyi Menkiti have one common thing. They hold on to a radical communitarian theory of person in African thought and for them the community determines the social, religious, political and moral being. This means community values take precedence over individual values and therefore the welfare of the individual must be seen from the stand point of the welfare of the community, since the individual cannot exist without community. The meaning of this is that in order personality, one must undergo a process of social and social transformation till one attains the full complement of excellence. It is in this regard that infants are not persons because they cannot be said to obey the norms of the community. Likewise the dead are also denied personhood simply on the ground that they are no longer within the human community. Menkiti (1984) says that the designation "it" is used for both the infant and the dead person; and in addition, infants are denied personhood because there is no ritualized grief at their death. The researcher holds that, while personhood is partly determined by communal values, fundamentally, there are other things apart from the community which make a human being enjoy the attribute of personhood. 
In fact Gyekye (1992) in particular supports this view when he argues that a person is endowed with certain attributes which are prior to community formation. "It is this attributes, such as, rationality, the capacity for virtue, ability to make moral judgment and to choose that confer personhood on the individual. Consequently, without these attributes, we cannot talk of the community, and the function of the community is to discover these various attributes and nurture them to maturity in various individuals. Personhood cannot be achieved or acquired because since the birth of a child, he or she has automatically become a person. Therefore the failure of having a social status (personality) does not strictly imply having no personhood.

A human person is a person whatever his age or social status. Personhood may reach its full realization in community, but it is not acquired or yet to be achieved as one goes along in society. What a person acquires are status, habits and personality or character traits: he qua person, thus becomes the subject of acquisition, and being thus prior to the acquisition, he cannot be defined by what he acquires. One is a person because of what he has acquired (Gyekye 1992).

At the same time we must recognize that individuals have their own wills and can choose their own goals. We must never endorse a form of 'tyranny' of the community over the individual. Even though the whole gamut of values and practices is a creation of the cultural community and is part of his history, this relationship does not imply that the community structure is the only factor the individual is required to consider in analyzing these goals.

Individual persons as participants in the shared values and practices, and enmeshed in the web of communal relationships, may find that aspects of those cultural givens are inelegant, undignifying or unenlightening and can thoughtfully be questioned and evaluated. The evaluation may result in individual's affirming or amending or refining existing communal goals, values and practices; but it may or could also result in the individual's total rejection of them. The possibility of reevaluation means surely that the person cannot be absorbed by communal or cultural apparatuses.

The researcher holds that by reserving for individuals the potential for responding to or rejecting the communal consensus, this gives identity to the individual, independent from any given community. This individual is able to define and determine his own identity. In fact for one to criticize oneself, one must be able to distance himself/herself from one's community or circumstances. This ability to look at one's culture with critical eyes make moral reformers possible. These reformers stand against the communal values but qualify as persons.

\subsection{Responsibility and Free Will}

An important condition for one to achieve personhood is the ability to act on the basis of rational reflection. One is regarded as not being a person proper if his/her behavior is unpredictable. The question that we ask here is: When is an individual responsible? We hold that an individual is responsible to the extent that his/her conduct can be modified through rational persuasion or moral correction. Where there is free will there is responsibility.

The normative idea of personhood depends on the metaphysical view that a person has volition, is autonomous, moral and capable of rational deliberation. A person is ascribed moral responsibility in terms of praise or blame...A person is not simply a determined object that is governed by communal rules over which he has no control. The absence of metaphysical features of personhood such as voluntariness or freedom implies that one cannot rationally act to meet communal obligations. Recognition is a validation of one's ability to act voluntarily and freely to meet one's responsibilities based on reason (Lee 2004).

Since there is a merit component to personhood, it is relevant to talk of the distribution of the opportunity of achieving personhood, so as to secure respect over and above the threshold respect that is due to human beings in virtue of their status. Goods like positions of prestige that are conferred to individuals who have achieved personhood are limited by their very nature, but given equality of opportunity, no person should be denied from the outset the chance to secure those goods.

The question here remains; what does the society do to those who are born incapacitated, in such away they are not in a position to achieve personhood in ways that able bodied people can? If another person is born in a family of thieves and the neighborhood is full of burglars, he didn't choose to be born in that family much less in the neighborhood and this affect his performance in an attempt to achieve personhood. How does one account for equality in unequal circumstances? The implication is that such people like idiots, senile, imbeciles, crating, kleptomaniac, or neurosis agents, moral outlaws, social deviants, dumb and deaf, even children (though potentially persons) are left out on the basis that they cannot fully (perhaps at the moment) fully actualize the salient characteristic feature for being a person. In view of the above, Wiredu and Gyekye (1992) looks at the Akan tribe and observes that an adult who behaves erratically or in an immature manner, and later changes, the inference may be revised. 
Provided that the behavior if found not to be deliberate or that she is not acting from her free will, the community will gather and it will be said of her a message of this tenure: "It is not her eyes, it is not her head, it is not her mind," that he/she is not responsible for the erratic actions. In this judgment the community will be changing irresponsibility to non-responsibility. It is against this background that we assert that free will and responsibility go together.

\subsection{Personhood and Social Status}

We recognize that there are standards for which individual persons aim that have an important role in how people think for themselves and their place in the society. But at the same time facts about a person's ambitions or goals do not add or subtract form that individual's status as a person.

The individual may fail in his strivings and, in the Akan Community, for example, may consequently be judged as a "useless person" (onipa hun), an opprobrium term. But it must be noted that what the individual would be striving for in all these exertions is some social status not personhood. The striving is part of the individual's self-expression, an exercise of a capacity he has as a person. Even if at the end of the day he failed to attain the expected status, his personhood would not for that reason diminish, even though he may loose social respect in the eyes of the community. So that it is the social status not personhood at which individuals could fail (Wiredu et al 1992). While persons may differ with respect to how they are treated in a community, we hold that this difference is a matter of the social status accorded each, not facts about their status as persons.

\subsection{The African concept of the human person and the wind of change.}

Africa like all other continents is deeply experiencing the effects of change in the world due to modernity in science, commerce, politics, communication, education, etc. Mbiti (1995) remarks that "now a new and rapid rhythm is beating from the drums of science and technology, modern communication and mass media, schools and universities, cities and towns. The man of Africa must get up and dance on the arena of the world drama." The image of the African person has changed because of this modernity. The African has changed his/her way of looking at him/herself and the universe. Such a change has impacted a great deal on personal attitudes and behavior as well as interpersonal relationships. At the heart of life in the traditional African community was the integral formation of the persona responsible and fruitful experience of life. Much has now changed. In contemporary society, some of the emerging issues are ignorance, erosion of the meaningfulness and evaluation of African values using Western criteria. This has led to the disintegration of the moral fabric of society, breakdown of the African family synergy, alienation of individuals and societies from their roots, giving rise to an individualistic society as opposed to communal life emphasized by the traditional African way of life.

\subsection{The Two Poles, Material and Spiritual}

Today the human being is caught between two poles, a material pole which in reality does not concern the true person but rather the shadow of personality or what in the strict sense is called individuality and a spiritual pole which does concerns true personality. It is to the material pole, the individual become centre of all (sic). On the other spiritual pole the person is the source of liberty and bountifulness (Maritain1947).

Individuality is here opposed to universality through which things are in mind. It designates that concrete state of unity and the division required by existence in virtue of which every actually or possibly existing nature can posit itself in existence as distinct from other beings.

This is today the root cause of an individual decides to live as an island with total disregard of others. But in the scale of values regarding the human species, no one is better than the other and no one is truly himself except when one is in full relationship with the others. According to the individualistic paradigm other people are regarded as of smaller and weaker extraction. Our adversaries are frogs, dogs and donkeys. Women we call bitches. Others become swine, monkeys, hyenas and the like. Others we see them as objects to be used, manipulated and discarded at will (Muluka 2008).

\subsection{Consequences of priority of the Individual over the Community}

With modernity, as indicated above, much has changed. This is because the community is no longer involved in the formation of the individual. For instance, rules governing sexual behavior are never enforced and with exposure to mass media the moral fabric is becoming more and more decadent. On this basis young people insist on independence regarding the type and style of dressing, type of friends, places and type of leisure activities. This is portrayal of the spirit of independency and individualism which was unacceptable in the traditional African setup. Indigenous education with its integral approach aimed at preparing the youth for responsible participation in the community's activities and for peaceful coexistence with the rest. Modern education undertaken in the same continent has a more universal dimension. It caters for the development of individual talents for academic excellence and career formation. 
The ideal person today is the most learned, the skilled, the rich and powerful among others, disregarding consistency in his behavior with the norms and ideals of personhood. Traditionally there was a close link between the elders and the youth to make sure they followed moral values of respect for life and other people's property, obedience, self- control, and descent behavior. Irresponsible behavior was severely punished. Contemporary rampant theft, swindling, embezzlement, cheating, injustice, suicide, abortion, gay marriages, divorce, rape and incest all attest to erosion of such values.

\subsection{Conclusion}

This paper has expounded on the communal aspect of the human person. It clearly has shown the importance of community to the individual and how the person acquires personhood and participates in the life of community. The researcher maintains that by the very fact that each individual is a person and expresses him/herself, s/he requires communication with the other in the order of knowledge and affection. Personality by its very essence requires dialogue in which individuals can properly communicate. However, one cannot avoid responding to the contemporary situation of African values. The paper contends that there is need to salvage some traditional African values like family synergy which is the foundation for recovering and promoting the African identity. This can be done in an interactive way that supports integration and adoption of values from other cultures to enrich African value systems rather than destroying them.

\section{References}

Beller, R., (2001), Life and Community in Africa: A way towards Inculturation with Spirituality of Focolare. Nairobi: Pauline Publications Africa.

Bujo, B.,(1988), "Can Morality be Christian in Africa" in C.H.I.E.A African Christian Studies, Vol. 4 No. 1, March. Fayemi, A.K., (2009) Human Personality and the Yoruba Worldview: An Ethico-Sociological Interpretation, The Journal of Pan African Studies, vol.2, no.9, Lagos: Lagos State University,

Gyekye, K., (1988) The Unexamined life: Philosophy and the African experienced, Accra: Ghana University Press, p.31-32

Gykye, K., (2001), "Person and Community in Africa thought", in African Philosophy Reader, eds. P.H. Coetzee-A.P.J Roux, London: Routledge.

Kanyike E., (2004), The Principles of Participation in African Cosmology and Anthropology, Balaka, Montfort Media. Kenyatta, J., (1965), Facing Mount Kenya, Traditional Life of the Gikuyu, Nairobi: Kenway Publications.

Lee B. M., (2004), African Philosophy: New and Traditional Perspectives, New York: Oxford University Press, p.199.

Maritain J., (1947, The Person and Common Good, trans. John J. Fitzegerald, New York: Charles Scribner's sons.

Mbiti J., (1990), African Religions and Philosophy, 2nd ed., Oxford: Heinemann Educational Publishers.

Menkiti, A.I., (1984), Person and Community in African Traditional Thought," in R.A. Wright (ed), African Philosophy: An Introduction, 3rd Edition (Lan Ham: University Press of America), .p. 172.

Muluka, B., In the Saturday Standard, "There is a greedy and Untamed beast in us that Scrambles for everything", Nairobi: The Standard Group, 4th October 2008.

Nkemnkia, M. N., (1999), Africa Vitology: A step forward in African Thinking, Nairobi: Paulines Publications Africa.

Ntumba, T., (1985), "Languange et socialite", primat de la Bisoite sur l'intersubjecive" in Richerches philosophique Africanies, vol II, Kinshasa.

Nyasani, J., (1991), The Ontological Significance of I and We in African Philosophy" in African Christian Studies Vol. 7 No. 1 53-62.

Olatunji, O., (2006), "The Individual community Relationship as an Issue in Social and Political Philosophy" in Core Issues in African Philosophy,

Rousseau, J. R., (1994), The Social Contract, trans. Christopher Betts: Oxford: Oxford University Press.

Senghor, S., (1964), On African Socialism, trans. Mercer Cook, New York: Praeger.

Shutte, A.,(1993), Philosophy for Africa. Rodenbosch: University of Cape Town Press, pg 46-47.

Temples, P., (1969), Bantu Philosophy, Paris: Presence Africane.

Segun, G., (1992) "Destiny, Personality and the Ultimate Reality of Human Existence: A Yoruba perspective," in International Studies in Philosophy, Vol. 17, No.1. Ikeja: Excel Publishers, p. 184. 